\section{Taking a stand}

\section{A protest by Chinese graduate students at Yale University has revealed the plight of a vulnerable workforce in} US labs. Geoff Brumfiel investigates.

ast month, Xuemei Han was at her wit's end. A second-year graduate student in the Department of Ecology and Evolutionary Biology at Yale University, she was facing expulsion. Efforts to transfer to the university's forestry school had failed, and it looked as though the 26-year-old might have to return to China within a matter of weeks. "I had a lot of pressure on me, and I did not feel confident anymore," she says.

In June, Han had been told that she was "not in good academic standing" with her department - an accusation she disputed. She had passed her qualifying exams at the first attempt and, after a few more tries, her required language exam as well. So she did something that many Chinese graduate students would never dream of doing: on 20 October she filed a complaint against Yale, accusing the university of treating Chinese students unfairly. The only Chinese student in her department, Han wrote in her complaint that she suspected professors were reluctant to work with her because they thought she would need extra help preparing manuscripts and grant proposals.

Her grievance quickly gained a high profile on campus and beyond. Three other graduate students filed supporting testimonials that detailed problems they had experienced in their departments, and just over half of the 274 Chinese graduate students at Yale signed a statement backing her. The case garnered media coverage in the United States and even made the evening news in China. Within a week, university administrators relented and allowed Han to transfer to the department of forestry, where she had found an adviser willing to support her.

Yale flatly denies any accusations of discrimination against Chinese students. Department members and administration officials declined to comment on the details of Han's case for legal reasons, but in a statement, Yale spokesman Tom Conroy said: "Yale has a long standing tradition of being a welcoming and supportive university for international students, and especially those from China."

Whether or not it was discrimination, Han's

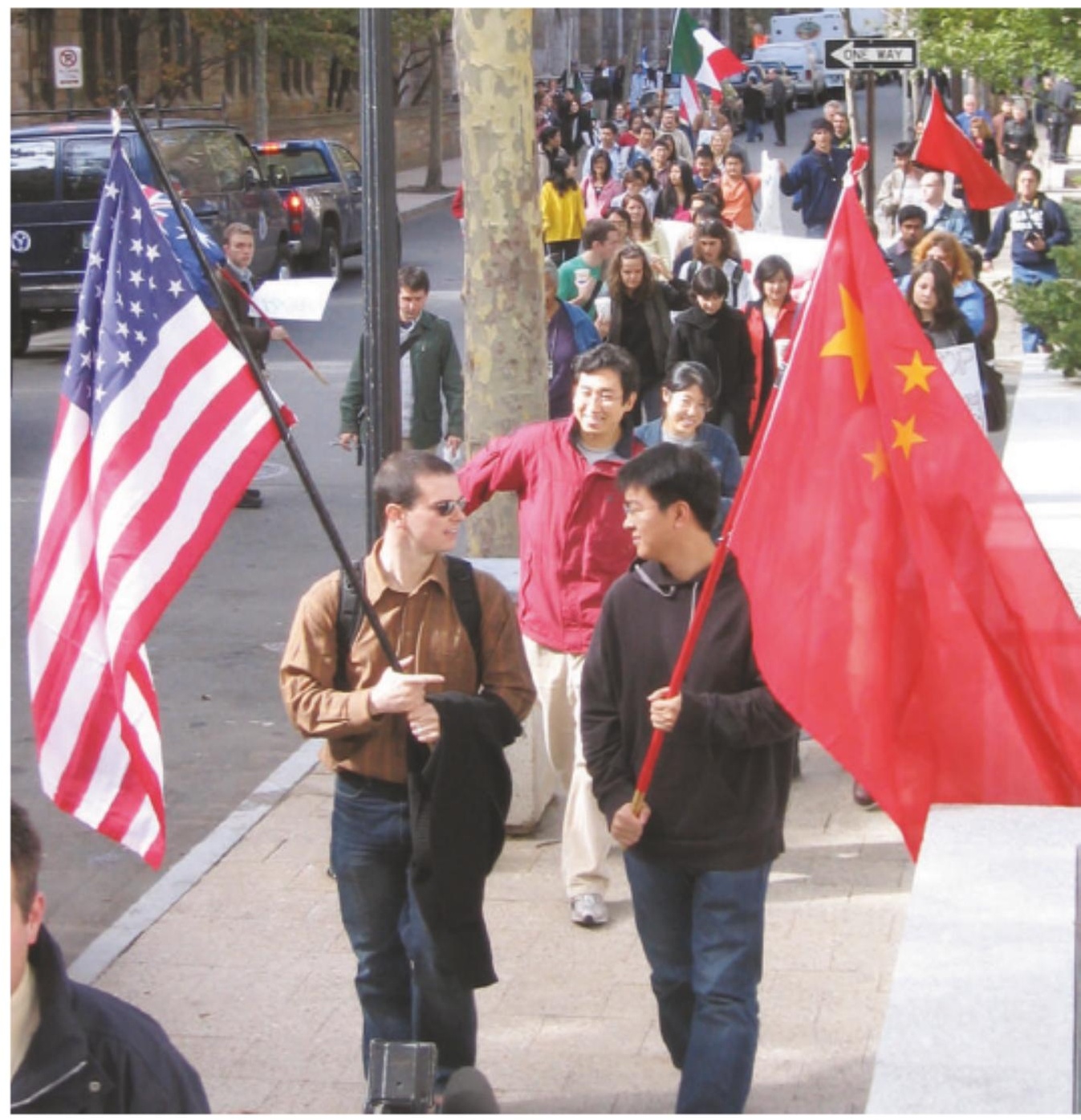

Yale students rally to highlight the problems faced by Chinese postdocs working in the UnitedStates.

story taps into a rarely seen vein of discontent among Chinese students and postdocs across the country. Chinese nationals are by far the largest group of foreign academics working in US universities. Between 1985 and 2000, some 26,500 Chinese students earned science and engineering $\mathrm{PhDs}$ in the United States - more than double the number of students from all of Western Europe, according to the National Science Foundation. And a recent survey of postdocs by scientific research society Sigma Xi in Research Triangle Park, North Carolina, showed that Chinese postdocs tend to work longer hours for less pay than their American counterparts (see graphic).

\section{Culture shock}

Many Chinese come to the United States to participate in cutting-edge research, but must first overcome language barriers, cultural differences and visa hassles. They frequently feel isolated from their US lab-mates. And although all graduate students are at the mercy of their advisers, foreign students are especially vulnerable. They lack alternative options, so a disagreement or funding problem is all that it takes for them to be sent back to China. "A lot of people live in fear," says Cong Huang, president of the Association of Chinese Students and Scholars at Yale and a third-year graduate student in the statistics department.

The high percentage of Chinese in the lab is no coincidence. US researchers are happy to recruit academically gifted Chinese scholars, while the best and brightest Chinese are drawn to the country by research opportunities that they cannot get at home.

That opportunity is what brought Han from Inner Mongolia to Yale in 2003. She received her undergraduate and master's degree in ecology from Beijing Normal University, but had never travelled outside China. "Ecology research has only just started in China, so my professors recommended that I study here," she recalls. She was ecstatic when she learned that Yale had admitted her to a PhD programme with funding from a Fan Family Fellowship, which supports Chinese students.

But shortly after arriving in the United States, Han ran into difficulty. Like many Chinese students, she had studied English extensively in China, but that training focused primarily on reading and writing, not speaking. "The first semester was very hard," she 
says. "In physics and other departments, there are other Chinese graduate students who can help, but I was the only one in my department."

Han's experience is not unusual. Many Chinese students have trouble fitting in when they first reach the United States, according to Hongwen Zhu, a graduate student at the Albert Einstein College of Medicine in New York. Zhu says many students are embarrassed to admit that they don't understand what is being asked of them, or they are reluctant to raise their concerns vocally with their professors. "Most Chinese students tend to be very quiet, and this is a verybig problem, ${ }^{\prime}$ he says.

Han made steady progress in her language skills, but it came at a cost. She was unable to teach, a requirement of her department, and she had trouble finding a research adviser.

\section{On the edge}

Still, Han was shocked to learn in June that she was no longer in good standing with her programme. The department told her that without an adviser she would be expelled from the programme on 31 August. With help from members of the ecology department, Han eventually found someone who was willing to advise her in Yale's forestry school. But when she tried to transfer, she was informed that she would lose the Fan Family Fellowship.

Foreign students and postdocs frequently run into these sorts of funding problems, says Ji-Cheng Wang, a postdoc cancer researcher at City of Hope Hospital in Duarte, California. Unlike American students, who can switch advisers if necessary, many foreigners are financially tied to their principal investigator (PI). "If anything happens to the PI then the student is put at risk, Wang says.

This relationship can put students in a precarious position. When Wei Fu, not his real name, moved from Peking University to became a postdoc at a midwestern university, he was hoping for a chance to expand his own research career in biophysics. Instead, Fu's lab director asked him to devote most of his time to existing experiments. "I didn't have much independence, I didn't feel free," he says. When Fu told the PI of his unhappiness, he found himself suddenly out of ajob. He had just three months to scramble for a new position, or risk expulsion from the country. Eventually, he managed to find a position at a lab in California. "You can imagine that I was very stressed," he says.

That stress has been exacerbated by recent US and Chinese immigration policy. Most international students and scholars get a multiple-entry visa for the duration of their studies, but Chinese students must reapply for a new visa every six months. That is an improvement over the old rules, which required students to reapply each time they left the country, but it still causes trouble for researchers such as Yangheng Zheng, a postdoc studying high-energy physics at the University of California, Los Angeles. While conducting

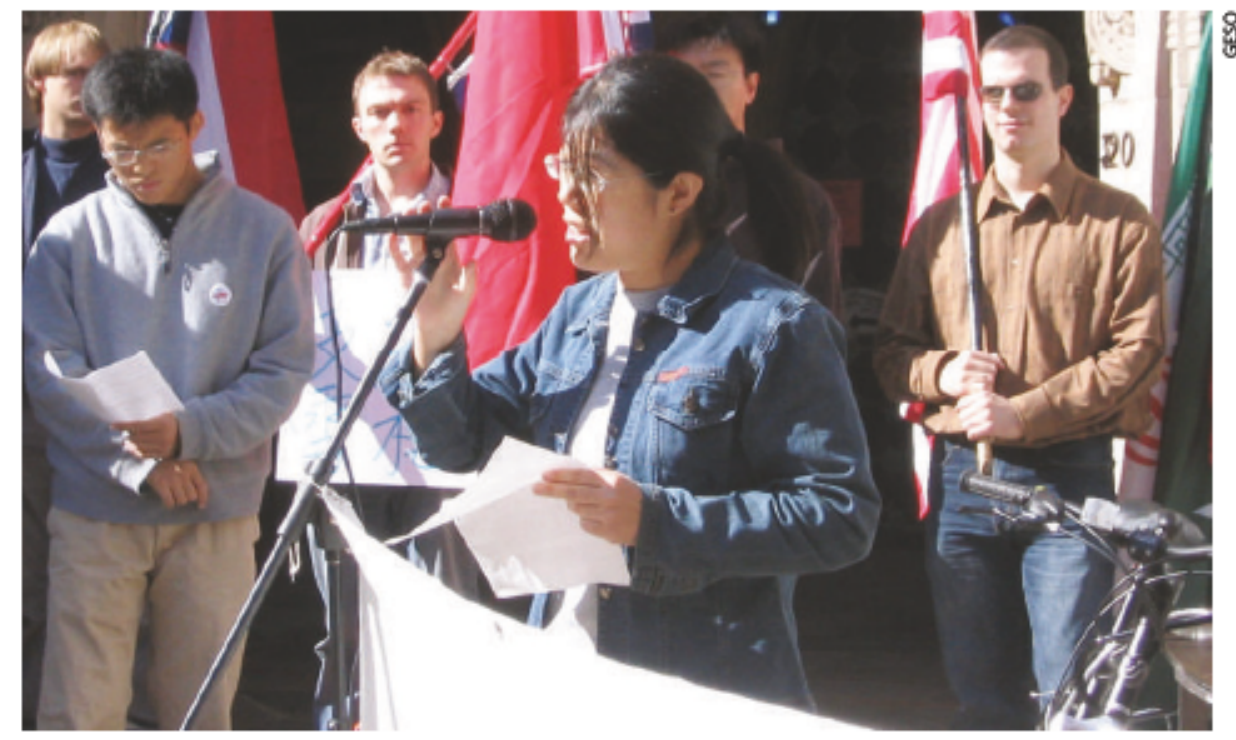

Speaking out: Xuemei Hanaddresses students protesting atherpossible expulsion from Yale University.

graduate research at the University of Hawaii, Zheng frequently travelled between the United States and Japan, and each trip required a new visa both ways. "In three years I used up all of my passport's pages, ${ }^{x}$ he says. Although the situation is better now, there are still problems, he says. Two months ago, on his latest excursion to CERN, the European particle-physics lab, he ended up stuck in Geneva for three weeks waiting for a US security check.

\section{Sink or swim}

There is little consensus in the Chinese community over how serious these issues are. Some students and postdocs that Nature spoke to said they had not encountered significant problems, and many reported strong relationships with their advisers, who helped them resolve issues. "The people I know are very nice to me," says Ye Jin, a postdoc in molecular biology at the University of California, Berkeley. ${ }^{\alpha}$ When I try to write papers and proposals my PI has been very patient and corrects my grammar. She has been very encouraging."

${ }^{\alpha}$ Language is not a barrier if you are willing

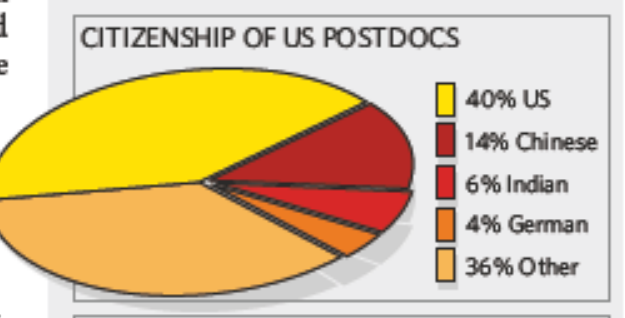

AVERAGE PAY DUS citizens $\square$ chinese citizens AND HOURS

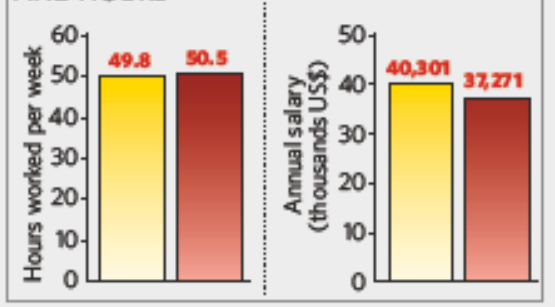

to learn," adds Grace Wong, the president of Student Vision, a Boston-based group that helps students find jobs in biotechnology. "If your skills are good and you're willing to work really hard, any boss will love you."

But Huang disagrees. "We really appreciate that the university gives us the chance to come here and study," he says. "But even if you work hard, sometimes you still have the risk of being kicked out because of a funding problem or a disagreement with your adviser." Huang's group, together with Yale's Graduate Employees and Student Organization, is now asking for modifications to the university's grievance process for international students.

Regardless of whether the issues are real or perceived, the United States has seen a decline in Chinese graduate students in recent years. First-time enrolments were down $8 \%$ in the 2003-04 school year - although they rose by $3 \%$ this year, according to the Council of Graduate Schools, a non-profit consortium of graduate educators. Heath Brown, director of research at the council, says that the decline was primarily the result of stricter visa policies after 11 September 2001, which made the United States seem less welcoming (see Nature 427, 190-195; 2004). Brown sees this year's reversal as "very positive", but he adds that much needs to be done to improve the image of the United States among Chinese students and scholars.

As for Han, now that Yale has allowed her to transfer to the forestry school and retain her fellowship, she says that she is "very happy". She hopes that her story will encourage others to speak up when they encounter trouble working or studying in the United States. ${ }^{\alpha}$ Most students don't know even one example in which a student fought and won," she says. "I hope that after me, more students will speak up for themselves."

Geoff Brumfiel is Nature's Washington DC physical sciences correspondent.

See Editorial, page 258. 